\title{
Ларина Т.H. \\ Смысложизненные стратегии как компонент саморегуляции в различных социальных контекстах
}

Описание смысловых образований и их взаимосвязей позволяет говорить о смысловой регуляции не как о частном, локальном феномене, а как об одном из главных компонентов психологической архитектоники человеческой жизнедеятельности. Это дает возможность раскрыть механизмы формирования и общую динамику различных личностных характеристик и прежде всего особенности саморегулящии как базовой характеристики личности.

Ключевые слова: Смысл, смысловые образования, смысложизненные стратегии, интегральная смысловая саморегуляция.

В современной общепсихологической теории дан конкретно психологический анализ феноменов и закономерностей смысловой регуляции жизнедеятельности человека. Сама феноменология смысла, а не просто объяснительный конструкт, исходит из понимания смысла жизни как концентрированной характеристики наиболее стержневой и обобщенной динамической смысловой системы, ответственной за общую направленность жизни субъекта как целого. Психологическую основу смысла жизни (в ряде публикаций в качестве синонима используется термин смысложизненная концепция личности) составляет «структурная иерархия системы больших и малых смыслов» (Чудновский В.Э., 1999).

Д.А. Леонтьев описывает данную урархию разновидностей смысловых структур личности, убедительно покрокая, что «за каждой из этих структур стоит содержательная феноменология лозволяющая говорить о смысле на языке конкретных, эмпиричеК наблюдаемых и доступных экспериментальному изучению проявлонй». Он выделяет шесть разновидностей смысловых структур - личностный смысл, смысловые установки, мотив, смысловая диспо цция смысловой конструкт и личностную ценность, которые соотносит с различьыми уровнями смысловой структуры.

К ситуативным смыслам он относит личностный смысл, смысловые установки и мотивы. Личност лй смысл в узком значении слова проявляет себя в феноменах трансфоу уаии пространственных, временных и других характеристик значимк 8 ббъектов в их образе. Смысловая установка проявляет себя в эффек ах стабилизирующего, преградного, отклоняющегося или дезорганизуюк ер влияния на протекание деятельности. Мотив проявляет себя в феномсн чаправленного побуждения деятельности, механизмы которого имего смысловую природу (смыслообразующий, а не стимульный мотив).

К Јстойчивым смысловым образованиям (структурам) Д.А. Леонтьев отност смысловые диспозиции и смысловые конструкты. Смысловая диегоиция обнаруживает себя в феномене сохранения смыслового отношения ъекту после завершния деятельности как устойчивого отношения, 
порождающего новые смыслы. Смысловой конструкт проявляет себя в смыслообразующем эффекте, не объяснимом ни мотивами, ни диспозициями.

Наконец высший уровень иерархии - высший смысл - понимается как личностная ценность, которая проявляет себя как стабильный источник смыслообразования и мотивообразования, берущий свои истоки в социокультурном целом, к которому принадлежит субъект (Д.А. Леонтьев, 2000).

Описание этих структур и их взаимосвязей позволяет говорить о смысловой регуляции не как о частном, локальном феномене, а как об одном из главных компонентов психологической архитектоники человеческой жизнедеятельности. Именно это дает возможность раскрыть механизмы формирования и общую динамику различных личностных характеристик и прежде всего особенности саморегуляции как базовой характеристики личности.

Проведенный анализ смысловых структур позволяет увидеть сложную организацию смысловой сферы, понять механизмы формирования различных смысложизненных стратегий и, как результат, причины возникновения и закрепления различных форм поведенческих реакций.

Говоря о стратегии, обычно имеют в виду своеобразный мыслительный акт, «свернутую внутри» операцию возможного действия, построение в уме реальности возможного действия. Иногда речь идет о бессознательных механизмах возникающих действий. С.И. Ожегов и Н.Ю. Шведова определяют стратегию как «вообще искусство планирования руковсдетва, основанного на правильных и далеко идущих прогнозах».

Идея смысложизненной стратегии историчеои связана с проблемой мотивации (А.К. Маркова и др., В.Э. Мильман, (‥ Моргун, Х. Хекхаузен), а также находит свое подтверждение и в исспедоңяиях о соотношении типа ценностей личности и ее успешности С своеобразном отношении к деятельности, к жизни и особенном миров сприяти.

Смысложизненная стратегия пџставляет собой частный случай более глобального, интегрального обра звашя - смысложизненной концепции личности. Можно сказать, что смысложизненная стратегия представляет собой динамическую проекцию смбупожизненной концепции личности на конкретные условия ее повседнзной жизни.

\section{Литература} исследования М., 198

1. Асмолов 8. Личность как предмет психологического

2. Асмоs ОВ А.Г. По ту сторону сознания: методологические проблемы неклаєанчекой психологии. М.: Смысл, 2002.

3. Братусь Б.С. К проблеме нравственного сознания в культуре уходящегяяєа // Вопросы психологии. 1993. № 1. С. 6-13.

4 Братченко С. Верим ли мы в ребенка!? Личностный рост с позищу гуманистической психологии // Журнал практического психолога. М.: Фюnyu, 1998. № 1. С. 19-31.

5. Братченко С.Л. Образование: ненасилие, толерантность и гуманистическая экспертиза // Век толерантности. 2001. № 3-4. С. 112-124. 